\title{
Assessment of Post-Harvest Losses of Major Fruit Crops at East Gojjam Zone, Amhara Region
}

\author{
Solomon Ali Gebeyehu \\ Department of Plant Science, College of Agriculture and Natural Resources, Debre Markos University
}

\begin{abstract}
Ethiopia has suitable agro-ecology to grow both temperate and tropical fruit crops. However, fruit production activity is at infant stage in most parts of the country including in Northwestern Ethiopia and both small scale fruit producers and traders have very limited knowledge and skill on fruit production and postharvest handling practices. In this connection high amount of fruit is expected to be wasted due to several inappropriate production and postharvest handling practices. Therefore, the objectives of this study were to assess fruit causes and extent of postharvest losses at Debre Markos. The study was conducted in April 2017 using semi structured questionnaire. 150 respondents from Farmers, Retailer and Wholesaler were randomly selected among Debre markos and their surrounding fruit Farmers, Retailer and Wholesaler those operating in Debre markos city to obtain information on postharvest losses. The total postharvest loss of fruit at farmer, wholesale and retail level were found to be $24 \%$ of which the higher proportion of losses $(35 \%)$ was observed at retail level while the loss at wholesale and farm levels were $14 \%$ and $21 \%$, respectively. Very high losses were observed due to transportation, marketing and postharvest mishandling at market level Therefore, multifaceted interventions such as capacity development, improved fruit production and harvesting practice, and proper storage and transportation facilities establishment are required to reduce postharvest loss and extend fruit shelf-life.
\end{abstract}

Keywords: Post-harvest, Proximate analysis and wholeseller

DOI: $10.7176 / \mathrm{JBAH} / 9-1-02$

\section{INTRODUCTION}

Ethiopia has suitable agro-ecology to grow both temperate and tropical fruit crops. However, fruit production activity is at infant stage in most parts of the country including in Northwestern Ethiopia and both small scale fruit producers and traders have very limited knowledge and skill on fruit production and postharvest handling practices. In this connection high amount of fruit is expected to be wasted due to several inappropriate production and postharvest handling practices. (Kughur et al. 2015)

According to FAO et al. (2012), The State of Food Insecurity in the World 2012, 870 million people were chronically undernourished during the years 2010-2012 and a majority is living in developing countries. The total percentage of people who does not have enough food in the world has declined since 1990 from 18.6 percent to 12.5 percent. In Western Asia, North Africa and Sub-Saharan Africa. However, an increase in undernourishment has taken place during the last years. In Sub-Saharan Africa 234 million persons, or 26.8 percent, did not have enough food available in 2010-2012 (FAO et al., 2012). Ethiopia is one of the Sub-Saharan African countries that are suffering from poverty and food insecurity as 40 percent of the population were undernourished during the years 2010 - 2012 (www, faostat, 1, 2014).

In order to reduce hunger and malnutrition and promote agricultural growth there is a great demand for investment and progress in the agricultural sector in many developing countries (FAO et al., 2012). Horticulture can be an important factor for economic development and contribute to increased food security and improve the populations' nutrition intake (Weinberger \& Lumpkin, 2007). The growing population and changing dietary habits in Ethiopia has increased the demand for fruit (ILRI, 2011). Especially the demand for local fruits with higher quality for example mango, banana, papaya, apple and avocado are emerging. The fruit production in Ethiopia has been small compared to other crops but it has a great potential since the climate is favorable for many horticulture products (Berhel et al., 2010). Two examples of fruits were the production have increased with over 60 percent during the last 10 years in Ethiopia is avocado and mango (www, faostat, 2, 2014; www, faostat, 3 , 2014). Food losses after harvest until the food reach the consumer are significant (www, FAO, 2, 2014). According to FAO (www, FAO, 2, 2014) post-harvest losses in developing countries can range from 15 percent up to 50 percent. Horticultural crops, such as fruits, are perishable products and therefore sensitive which leads to greater losses than for non-perishable crops (Parfitt et al., 2010). To increase food availability, it is therefore not enough to increase the productivity in agriculture there is also a need to lower the losses. A problem in the supply chain for fruits in Ethiopia is that the knowledge about post-harvest handling is limited and the postharvest losses are high (ILRI, 2011; Wakijira, 2010). Losses occur in all post-harvest activities such as handling, storage, processing, packaging, transportation and marketing. Handling and processing of the food are of high importance in order to ensure food-safety reduce losses (Kader, 2003).

In order to define post-harvest losses, it is important to do a systematic analysis of the production and handling system and therefore the supply chain for the product (Bell et al., 1999). For tropical food supply chains 
for products such as mango and avocado there are common features and characteristics (Ruben et al., 2007). There is often large variations in the supply of products and variability in product quality due to different growing seasons, weather changes and production technology used. The production is mostly scattered and undertaken by a large number of small farmers which are producing for local markets with a limited amount of traders. To reach more central markets there is commonly a large number of middlemen between the producers and consumers (Shukla\&Jharkharia, 2013).

The access to information, new production technology, credit and external services are constrained in many supply chains in developing countries and the infrastructure are often weak (Trienekens, 2011). Major causes for food waste are insufficient operational activities within supply chains, such as handling, storage and transportation (Murthy et al., 2009). In food supply chain management, the major concerns are post-harvest losses. An efficient supply chain management can therefore be a way to decrease post-harvest losses (Shukla\&Jharkharia, 2013). In many developing countries there is a demand for more knowledge about postharvest loss management and implementation of improved post-harvest technologies (Kitinoja et al., 2011).

\subsection{Problem statement}

As stated in the previous section there is a great need of increased food security in Ethiopia and the horticulture production can be part of solving this problem. Research also shows that post-harvest losses contribute to undernourishment and food insecurity in developing countries. The losses occur within the whole supply chain due to limited resources such as post-harvest technology, knowledge and infrastructure (Parfitt et al., 2010). The losses for horticulture products, such as mango and avocado, are more complex as they are perishable products and depending on climate conditions (Van der Vorst \&Beulens, 2002; Salin, 1998). Horticulture can apart from increasing food security also be an opportunity to increase the income for small-holder famers. In order to increase food security, it is not enough to increase the productivity in agriculture but there is also a great need to lower the losses (Parfitt et al., 2010). Horticulture research has historically focused on how to increase the production and little emphasis has been made on how to minimize post-harvest losses (Kitonja et al., 2011). The amount of losses within a supply chain is dependent on activities such as handling, storage, processing, packaging, transportation and marketing (Kader, 2003). It is though not only the activities undertaken by the actors within the chain that affect the performance (Trienekens, 2011). The interactions between the actors and external factors such as governance structures, market access, infrastructure and information flow also have impact on the performance and level of efficiency to reduce the losses.

Higher postharvest losses not only reduce the availability of fruits but also result in increase in per unit prices of the produce and thus limit the accessibility by the majority of community segments. Kughur et al. (2015) pointed out the multiple effects of postharvest loss as going beyond the loss of the actual crop to include loss in the environment, resources, labor needed to produce the crop and livelihood of the individual involved in the production process. However, it is important to note that much is being invested to production compared to postharvest handling, though 30 to $50 \%$ of the produce is wasted in few days after harvest. So far there are very limited reports on the causes and amount of fruit postharvest loss in Ethiopia. However, there was no information on the cause and extent of fruit post-harvest loss in Debre Markos. Therefore, the present study was conducted to assess post-harvest losses of major fruit at Debre Markos market.

\section{Material and methods}

\subsection{Study area}

The study was conducted in Debre Markos market in the year 2017. Debre Markos, the capital of East Gojjam Administrative Zone is located in the northwest of the capital city of Ethiopia, Addis Ababa at a distance of 300 $\mathrm{Km}$ and $265 \mathrm{Km}$ to the capital of Amhara Nation Regional State Bahir Dar. The Geographical location of the study area is located between $10^{\circ} 17^{\prime} 00^{\prime \prime}$ to $10^{\circ} 21^{\prime} 30^{\prime \prime} \mathrm{N}$ Latitudes and $37^{\circ} 42^{\prime} 00^{\prime \prime}$ to $37^{\circ} 45^{\prime} 30^{\prime \prime} \mathrm{E}$ longitudes and its elevation ranges in altitude from 2350-2500 meters above sea level. The town has $1380 \mathrm{~mm}$ average annual rainfall and minimum and maximum temperatures of $15{ }^{\circ} \mathrm{C}$ and $22^{\circ} \mathrm{C}$, respectively.

\subsection{Sampling Procedure and research design}

150 respondents from Farmers, Retailer and Wholesaler were randomly selected among Debre markos and their surrounding fruit Farmers, Retailer and Wholesaler those operating in Debre markos city. The survey was conducted in April 2017 using semi-structured questionnaire following individual interview method.

\subsection{Preparation of structured questionnaires}

For the loss assessment study this research was used a standard and well prepared tool published by FAO. A postharvest loss assessment method as Commodity Systems Assessment Methodology (CSAM) was originally developed by Jerry LaGra (1990), and modified during its implementation over the course of many years. Modification of some components into our local context has been made. 


\subsection{Data Collection}

Both qualitative and quantitative data including sex, age, education level and length of fruit marketing experience of respondents, type of fruit they are selling, type of packaging material, transportation method, storage facility, source of fruit, percentage of fruit loss, percentage fruit loss in different seasons, possible uses of over-ripen fruits, and measures taken by respondents to reduce postharvest losses were collected using the questionnaire.

\subsection{Data Analysis}

The data generated from the questionnaire was analyzed using a template before applying descriptive statistics of frequency and percentage (Trochim, 2006). Statistical Package for the Social Sciences (SPSS) and STATA 8 program where used to generate data.

\section{RESULTS AND DISCUSION \\ 3.1 PRODUERS}

\subsubsection{Time of harvesting}

The results for harvesting time of the fruits presented in Table shows the respondents $(34.21,31.58,28.83$ and, $5.26 \%$ ) harvest fruits early in the morning, Evening, Anytime of the day and Afternoon respectively. Kereth et al. (2013) reviewed that $95 \%$ of farmers harvested fruits in the morning in a study conducted in Bagamoyo district of Tanzania.

Harvesting in the afternoon has been reported to be a cause of high postharvest losses because of high temperatures and evaporation which causes the fruit to shrink, thus affecting the marketing quality. Similar results have been reported by Genova et al. (2006) and Kereth et al. (2013) that harvesting activities should be completed during the coolest time of the day, which is usually in the early morning and produce should be kept shaded in the field and handled gently.

In study area $26.39,18.42,17.27$ and $7.89 \%$ of respondent harvest fruit at the stage of full ripe, Green mature, half mature and immature respectively.

\subsubsection{Types of fruit Crop in study area}

The fruit grown in the study area include Mango Avocado Apple and Banana as shown in table above. They reported that $(60.53 \%, 21.85,10.53$ and $7.89 \%)$ of farmers who participated in the study are cultivated Mango, Avocado, Banana and Apple respectively.

\subsubsection{Fruit packaging materials}

Fruit packaging has significant importance in reducing postharvest losses through protecting fruits from mechanical damage, undesirable physiological changes and pathological deterioration during storage, transportation and marketing. In the study area, farmers use different packaging materials to transport and store fruit crops. About 60.0830 .096 .673 .33 \% respondents reported, Basket, Sack/bag, Leaf Plastic cart as their fruit packaging materials, respectively. Seid et al. (2013) reported sack as the major fruit packaging material in South Wollo zone, Ethiopia. Transporting fruits without packaging material will increase fruit spoilage by predisposing the fruit to mechanical damage during loading and unloading as well as during driving on rough road.

\subsubsection{Method of transportation to local store}

Farmers transport both from distant and nearby areas. Therefore, they are using different transportation methods in above table about42.11, 34.21, 21.05, \% of respondents reported that fruits are transported using women's back, using animal driven cart, and using man shoulder usually from distant areas. All transportation methods predispose fruits to heat buildup and mechanical damage. Therefore, the present fruit transportation method contributes for fruit postharvest loss. Seid et al. (2013) reported pack animals as major transportation system of fruit from production site to the local market in South Wollo zone, Ethiopia.

\subsubsection{Time until loading to market}

Above table shows that produce storage prior transporting to the market ranged from $1 \mathrm{hr}$ to a maximum of one day. These results show that some farmers (zero storage time) harvested and delivered to the market at the same time without storing the produce at the farm. Considering that none of the farmers in the study area have cold storage facilities at their farms, storage of produce for long periods such as 0ne day as reported in Table above is a contributory factor to high postharvest losses. This will result in rapid quality loss of the fruits especially in summer when temperatures are generally high. Minimizing the time spent keeping harvested produce at the farm will help in reducing postharvest losses as suggested by Kader (2005) who argued that as the time the produce stays in the market increase from the time of purchase, its deterioration also increases.

About 57.69, 18.53, 15.79 and $15.79 \%$ of respondents reported heaping under shade and covering with leaf, heaping in open air, heaping in open space and covering with leaf and others materials respectively. 
Fig 1 factors for quality deterioration

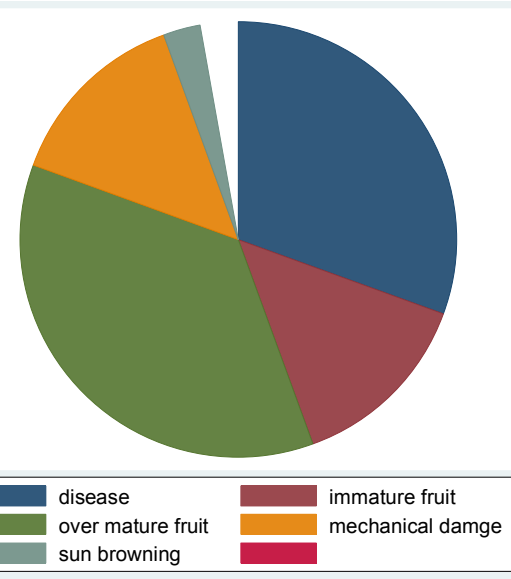

\section{Parameter}

Type of packing material

Time until loading to market

Store until loading

For whom you sell

Why you prefer whole buyer

You sell all

Why not all

Reason for reduced quality

Percentage fruit of unsuitable for market

\begin{tabular}{l} 
Leaf \\
Basket \\
Sack/bag \\
Plastic cart \\
\hline$<2$ hr
\end{tabular}

$<2 \mathrm{hr}$
half a day

one day

heaping in open space and covering with leaf $\quad 6 \quad 15.79$

heaping under shade and covering with leaf $\quad 22 \quad 57.69$

heaping in open air $\quad 4 \quad 18.53$

$\begin{array}{lll}\text { others material } & 6 & 15.79\end{array}$

$\begin{array}{lll}\text { collectors } & 5 & 13.19\end{array}$

$\begin{array}{lll}\text { wholesalers } & 2 & 4.26\end{array}$

cooperatives $\quad 2 \quad 4.28$

$\begin{array}{lll}\text { retailers } & 21 & 55.26\end{array}$

$\begin{array}{lcc}\text { consumers } & 8 & 21.08\end{array}$

\begin{tabular}{lll}
\hline better price & 13 & 34.21
\end{tabular}

$\begin{array}{lll}\text { customers } & 9 & 23.68\end{array}$

quality discrimination $\quad 112.63$

$\begin{array}{lll}\text { large volume of purchase } & 15 & 39.17\end{array}$

$\begin{array}{lll}\text { yes } & 9 & 23.91\end{array}$

$\begin{array}{lll}\text { No } & 29 & 76.12\end{array}$

quality problem $\quad 21 \quad 58.33$

low price $\quad 3 \quad 13.66$

own consumption | $\quad 2 \quad 12.61$

reduced interest of buyer $\quad 2 \quad 13.1$

quality discrimination $\quad 1 \quad 2.63$

$\begin{array}{lll}\text { improper production practice } & 10 & 43.24\end{array}$

$\begin{array}{llll}\text { inefficient care during harvesting and } 16 & 51.35\end{array}$

transportation

inadequate storage facilities $\quad 3 \quad 5.41$

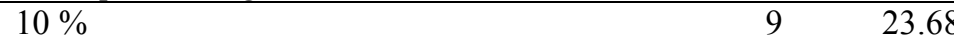

$20 \% \quad 14 \quad 36.84$

$30 \% \quad 13 \quad 34.21$

$40 \% \quad 2 \quad 5.26$

Table 1. factors that contributing postharvest loss at farmer level with respected loss percentages

\subsubsection{Factors for quality deterioration}

Causes of fruit postharvest losses are usually interrelated. Therefore, respondents requested to rank causes of fruit postharvest losses in terms of their contribution on fruit spoilage. These responses are given in Table 1, About36.11, 30.56, 13.89, 13.11 and $4.26 \%$ of respondents ranked over mature fruit, mechanical damage, 
Immature fruit and sun browning as cause for high postharvest losses. From these observations, it is evident that the major factor causing the loss of the produce was mature fruit followed by mechanical damage and immature fruit finally poor quality of the produce. Our findings substantiate the report by Mbuk et al. (2011) who reported that mechanical damage and softening had significant effect on postharvest losses of fruit. Similarly, FAO (2004),), mechanical damage identified as important determinants for the postharvest loss fruit.

\subsubsection{Percentage of fruit unsuitable for market}

Table 1 shows that the percentage of fruits lost at farmer level: on average, $24 \%$ of the fruit were lost. Kughur et al. (2015) reported 35 to $45 \%$ postharvest loss on fruit and vegetable in Nigeria. About $33.3 \%$ postharvest loss is not affordable for a country with large number of food insecure population.

\subsection{RETIELAR RESULT DISCUSSION}

As indicated in Table 2 and figure 2, climate and seasonal conditions, harvesting and handling techniques, packaging, storage and transportation and market situations were mentioned by almost equal proportion of respondents. Factors such as disease and Mechanical damage was mentioned by relatively less number of respondents.

Post-harvest loss and quality deterioration of horticultural crops occurred due to lack of proper care, use of inappropriate harvesting equipment and materials and lack of motivation and interest to improve and upgrade the harvesting and handling techniques from time to time. Problems related to packaging, storage and transportation facilities as factors for horticultural crops loss and quality deterioration were stated by the respondents. Marketing situation as major cause of post-harvest loss and quality.

Table 2. factors that contributing postharvest loss at Retailer level with respected loss percentages

\begin{tabular}{|c|c|c|c|}
\hline \multicolumn{2}{|l|}{ Parameter } & Freq. & Percent \\
\hline \multirow[t]{3}{*}{ Amount of fruit bought } & $50 \mathrm{~kg}$ & 31 & 75.61 \\
\hline & $100 \mathrm{~kg}$ & 9 & 21.95 \\
\hline & $200 \mathrm{~kg}$ & 1 & 2.13 \\
\hline \multirow[t]{3}{*}{ Amount of fruit sold } & $50-69 \mathrm{~kg}$ & 29 & 79.74 \\
\hline & $70-89 \mathrm{~kg}$ & 6 & 14.63 \\
\hline & $90-100 \mathrm{~kg}$ & 6 & 14.63 \\
\hline \multirow[t]{2}{*}{ You sell all fruit you bought } & no & 39 & 95.12 \\
\hline & yes & 2 & 4.88 \\
\hline \multirow{3}{*}{$\begin{array}{l}\text { Reason if you couldn't sell all the fruit you bought (if the } \\
\text { above answer is No ) }\end{array}$} & poor quality & 29 & 67.99 \\
\hline & own consumption & 2 & 4.88 \\
\hline & reduced market demand & 11 & 26.83 \\
\hline \multirow[t]{3}{*}{ If the reason is poor quality prioritizes } & softening-rotting-MD & 5 & 12.20 \\
\hline & softening--MD-rotting & 14 & 34.15 \\
\hline & Md-rotting-softening & 22 & 53.66 \\
\hline \multirow[t]{3}{*}{ Percentage unsuitable for market } & $10 \%$ & 7 & 17.07 \\
\hline & $15 \%$ & 21 & 51.22 \\
\hline & $20 \%$ & 13 & 31.71 \\
\hline \multirow[t]{4}{*}{ Percentage of fruits which is consumed at home } & $3 \%$ & 35 & 85.37 \\
\hline & $6 \%$ & 4 & 9.76 \\
\hline & $7 \%$ & 1 & 2.44 \\
\hline & $10 \%$ & 1 & 2.44 \\
\hline \multirow[t]{2}{*}{ Supply shortage } & Yes & 33 & 80.49 \\
\hline & No & 8 & 19.91 \\
\hline \multirow[t]{2}{*}{ In Which season the Supply shortage encounter } & Summer & 19 & 46.34 \\
\hline & Winter & 22 & 53.66 \\
\hline \multirow[t]{2}{*}{ Seasonality of demand } & Yes & 19 & 13.34 \\
\hline & No & 22 & 53.66 \\
\hline \multirow[t]{2}{*}{ In which season the demand raise } & Summer & 23 & 56.10 \\
\hline & Winter & 18 & 43.90 \\
\hline \multirow[t]{2}{*}{ In which season the demand fail } & Summer & 17 & 41.46 \\
\hline & Winter & 24 & 58.54 \\
\hline \multirow[t]{2}{*}{ Is the Price vary } & Yes & 28 & 68.29 \\
\hline & No & 13 & 31.71 \\
\hline \multirow[t]{2}{*}{ When the price rise } & Summer & 21 & 51.22 \\
\hline & Winter & 20 & 48.78 \\
\hline
\end{tabular}


Fig 2 types of packaging material of fruit

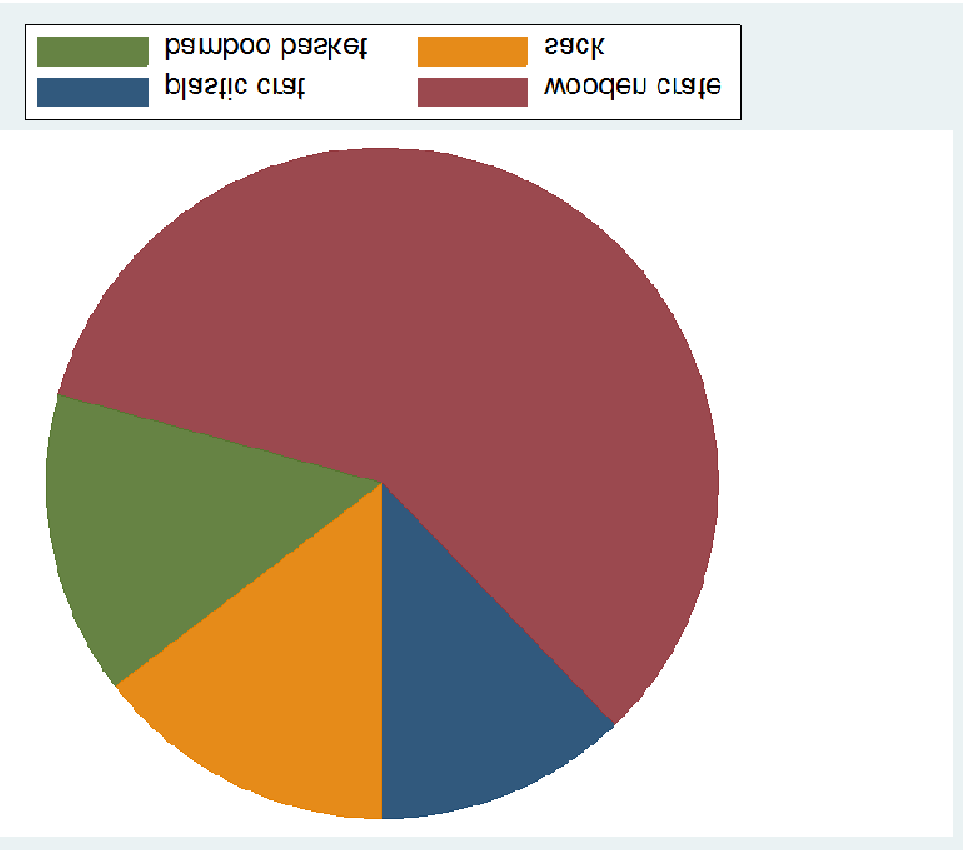

Fig 3 types of storage material used to Store fruit

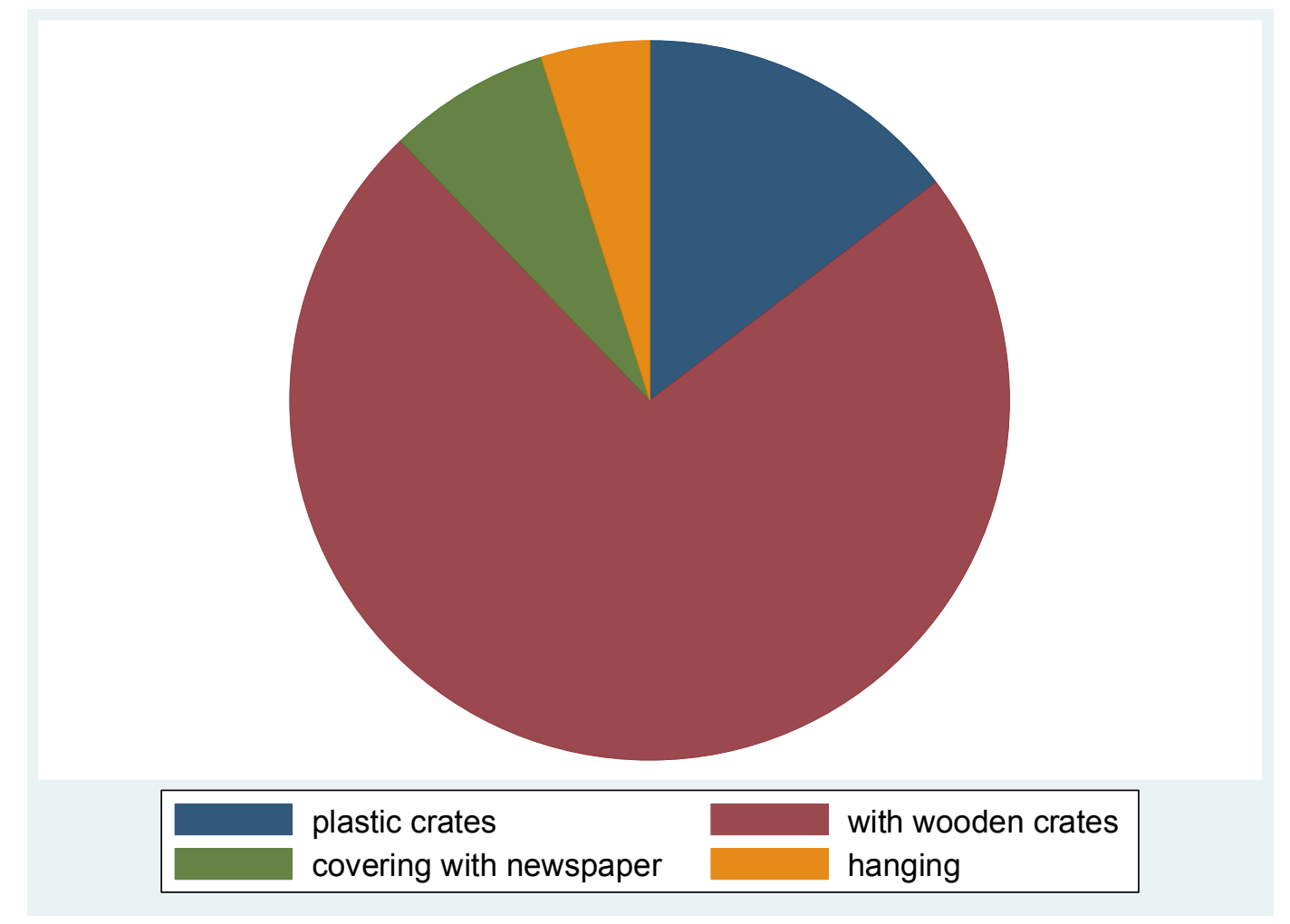


Fig 4 types of displaying material used to display fruit

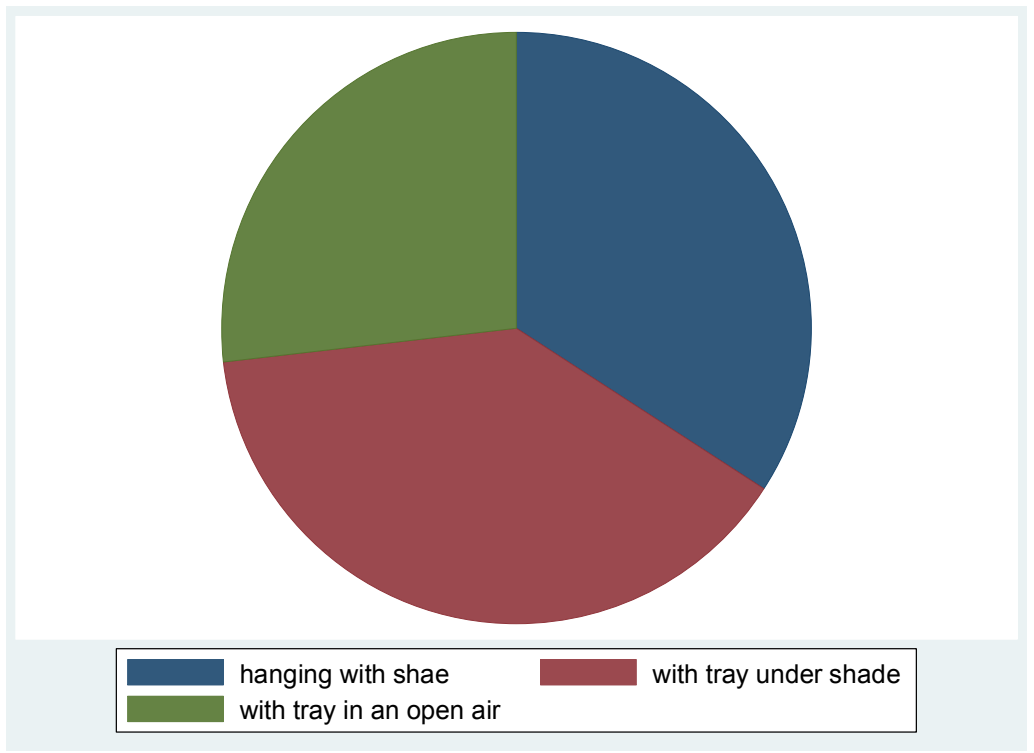

\section{Discussion}

The horticultural crops are inherently liable to deteriorate under different climatic and other circumstances due to their high moisture content (Kitinoja and Kader, 2002). Moreover, as they are biologically active and carry out transpiration, respiration, ripening and other biochemical activities, they tend to loss and deteriorate through time. This makes the post-harvest losses to occur in the field, packing areas, in storage, during transportation and marketing. Severe losses occur because of environmental conditions, poor facilities, lack of know-how, poor management, weak marketing processes or simply due to carelessness of farmers. Proper storage conditions, temperature and humidity are needed to lengthen the storage life and maintain quality of horticultural crops (Kitinoja and Kader, 2002). This has a negative effect on most horticultural products as a major factor for postharvest loss and quality deterioration. Horticultural crops may be characterized as being either climacteric or non-climacteric, depending on their respiratory pattern. Climacteric fruits can be harvested when mature but before the onset of ripening. After the climacteric, the respiration rate slows down as the fruit ripens and develops quality (Sirivatanapa, 2006).

Mechanical damage during harvest can become a serious problem by disposing it to decay, increasing water loss, respiration and ethylene production rates, which leads to deterioration (Kitinoja and Kader, 2002). Bruises and other mechanical damage affect appearance and also provide entrance to decaying organisms (Olayemi et al., 2010).

The majority of respondents seem to harvest during relatively appropriate time concerned with temperature and humidity, although night or early morning harvesting is used to lower internal temperatures and used for reduction of the energy needed for subsequent cooling (Kitinoja and Kader, 2002).

The severe horticultural crop post-harvest loss and quality deterioration were recorded mostly during harvesting followed by marketing, transporting, storage and in some cases through the entire channel. This is because fresh produce after harvest continues the process of respiration and transpiration until its reserved food and water are exhausted (Sirivatanapa, 2006). This physiological process is influenced by temperature, composition of surrounding air, and humidity of environment. Although harvesting was carried out by hand rather than machine, some horticultural crops can be severely damaged by careless and inappropriate harvesting Absence of the use of maturity index as a standard cause high post-harvest loss and quality deterioration (Kitinoja and Kader, 2002).

The use of transportation on rough road and open and closed lorry including public buses causes mechanical damage to horticultural crops as a result of vibrations and high temperature (Singh and Singh, 1992). The use of poor packaging material that restricts ventilation will also cause post-harvest loss and quality deterioration of horticultural crops (Olayemiet al., 2010). The desired level of development in horticulture has not been achieved because of a number of constraints. Due to absence of proper storage and marketing facilities, and seasonal surplus, farmers are forced to sell their products at thrown-away prices and at the earliest opportunity after harvest (Wei et al., 2001). This also forces producers to sell their horticultural crops at very low prices for their customers. Furthermore, the lack of ability in business planning, lack of marketing knowledge and the perish ability of their products contribute to their weak influential position in the supply chain (Wei et al., 2001). 
The estimated post-harvest losses of fruits and vegetables range from $20 \%$ to $40 \%$ (Wiersinga and de Jager, 2009). Increased returns to growers might come from proper management after harvest (Wiersinga and de Jager,2009).

The increasing horticulture production can contribute to the commercialization of the rural economy and creates many jobs. However, expanding the scale of horticulture production is often hindered by lack of market access, market information and many biological factors (Abay, 2007). BezabihandHadera, (2007) also argued seasonal production to be inversely related to price. Information on price, product demand, product supply, market place and buyers and sellers should be gathered.

\subsection{Postharvest loss at wholesale level}

All respondent from wholesaler side distribute banana. fruit Mechanical damage was also mentioned by majority of the wholesalers $(60 \%)$ as the main cause for fruit(banana) loss at wholesale level while failure to pulp softening and improper maturity were noted by the remaining $25 \%$ and $15 \%$ of the respondents, respectively (Figure 2). The processes of fruit handling and packing from harvest through transport and marketing might contribute for mechanical damage to banana at whole sale market. Poor handling, unsuitable containers, improper packaging and transportation are indicated to easily cause bruising, cutting, breaking, impact wounding and other forms of injury leading to fruit deterioration (delAguilaet al., 2010). Similar results were reported by Ilayaset al. (2007) stating higher mechanical damage to bananas at whole sale and retail marketing than at harvesting level within the supply chain.

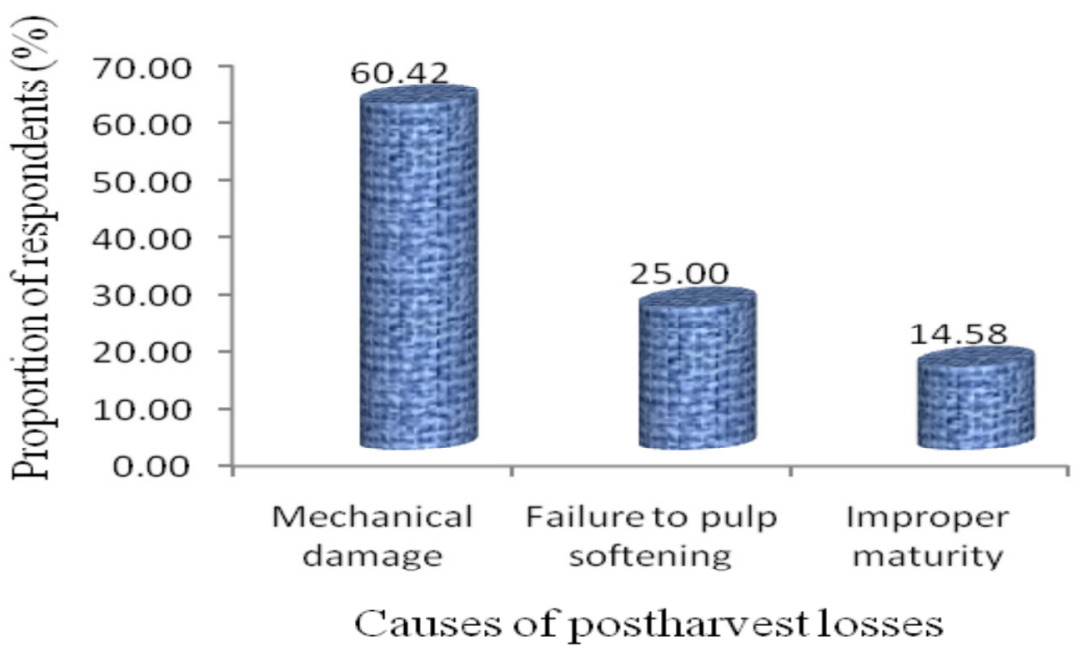

Figure 5. postharvest loss of banana at wholesale level.

\subsection{Extent of losses}

The total postharvest loss of fruit at farmer, wholesale and retail level were found to be $24 \%$ of which the higher proportion of losses (35\%) was observed at retail level while the loss at wholesale and farm levels were $14 \%$ and $21 \%$, respectively. The high percentage loss observed at the retail level could be accounted for the cumulative effect of improper handling from harvest to retail level. The perishable nature of ripe fruits also makes the problem worse at the retail level. The relatively lower magnitude of loss at farmer and wholesale level could be explained by the fact that farmers and wholesalers are mostly dealing with green fruits. Moreover, the damage is prevalent later at ripening; green fruits are more tolerant to handling problems. Similar to this, lower losses were reported by Wanjari and Ladaniya (2004) for unripe bananas compared to the ripe ones. Table 4. Postharvest loss of banana at farm, wholesale and retail level

\begin{tabular}{rrrr}
\hline \multicolumn{1}{r}{ Supply chain } & & Loss \% & Share in total (\%) \\
\hline Wholesaler level & 4.5 & 17 \\
\hline Retailer level & 7.1 & 26.8 \\
\hline Total & 14.9 & 56.2 \\
\hline
\end{tabular}

\section{SUMMERY AND CONCLUSSION}

Ethiopia has suitable agro-ecology to grow both temperate and tropical fruit crops. However, fruit production activity is at infant stage in most parts of the country including in Northwestern Ethiopia and both small scale fruit producers and traders have very limited knowledge and skill on fruit production and postharvest handling 
practices. In this connection high amount of fruit is expected to be wasted due to several inappropriate production and postharvest handling practices. Inappropriate storage, packaging and transportation practices are identified as principal causes for the $24 \%$ fruit postharvest loss in the study area. About $24 \%$ postharvest loss is not affordable for a country with 1 food insecure population. Therefore, efforts required on fruit storage and transportation infrastructures establishment, fruit processing, and capacity development to reduce the recorded high fruit postharvest loss and make available for consumers throughout the year.

\section{RECOMMENDATION}

In general, the mishandling during harvesting, packaging, transportation and storage and unfavorable climatic condition and contamination are causing mechanical, pathological and physiological damage. The support given for the improvement and reduction of post-harvest loss and quality deterioration of horticultural crops from concerned bodies is low and insufficient. Therefore, urgent intervention to the existing problems is highly required. In addition, an effective and efficient intervention policies and strategies need to be developed.

\section{REFERENCE}

Abay, A., 2007. Vegetable market chain analysis in Amhara National Regional State: the case of Fogera Woreda, South Gondar Zone. M.Sc. Thesis. Haramaya University.

Babalola, D.A., Makinde, Y.O., Omonona, B.T. And Oyekanmi, M.O. (2010) Determinants of post- harvest losses in tomato production: a case study of Imeko - Afon local government area of Ogun state. Journal of Life and Physical Sciences, 3(2): 1418.

Babalola, D.A., Megbope, T.A. And Agbola, P.O. (2008) Postharvest losses in Pineapple production: A case study of Ado-odootta Local Government Area of Ogun State. Bowen Journal of Agriculture 5(2): 55-062.

Bell, A., Mazaud, F. \&Mück, O., 1999. Guidelines for the analysis of postproduction systems. FAO, Rome, Italy

Bezabih, E., Hadera, G., 2007. Constraints and problems of horticulture production and marketing in Eastern Ethiopia. Dryland Coordination Report, G46, Osolo, p. 91

Buyukbay, E.O., Uzunoz, M. And Sibel, G.B.H. (2011) Post-harvest losses in tomato and fresh bean production in Tokat province of Turkey. Scientific Research and Essays, 6 (7):

Clayton, D.A. And Griffith, C.J. (2008) Efficacy of an extended theory of planned behavior model for predicting caterer's hand hygiene practices. International Journal of Environmental Health Research, 18(2): 83-9

Food and Agriculture Organization (FAO) (2011) Appropriate food packaging solutions for developing countries. Save Food I nterpack Congress held on 16 - 17 May 2011 in Dusseldorf, Germany. Rome: FAO.

Food and Agriculture Organization (FAO) (2005) FAO and the challenge of the Millennium Development Goals: The road ahead. Rome: FAO.

Food and Agriculture Organization (FAO) (2004) Socio-economic analysis and policy implications of the roles of agriculture in developing countries: Summary report for the Roles of Agriculture Project. Rome: FAO

FAO, IFAD \& WFP, 2012. The State of Food Insecurity in the World 2012: Economic growth is necessary but not sufficient to accelerate reduction of hunger and malnutrition. FAO, Rome.

FAO, Food and Agriculture Organization of the United Nations. (www.FAO.org)

Food and Agriculture Organization (FAO) (2011) Appropriate food packaging solutions for developing countries. Save Food Interpack Congress held on 16 - 17 May 2011 in Dusseldorf, Germany. Rome: FAO.

Food and Agriculture Organization (FAO) (2005) FAO and the challenge of the Millennium Development Goals: The road ahead. Rome: FAO.

Holloway, G., Nicholson, C., Delgado, C., Staal, S. And EhuI, S. (2000) Agro-industrialization through institutional innovation: Transaction costs, cooperatives and milk-market development in the East-African highlands. Agricultural Economics, 23(3): 279- 288.

Idah, P.A., Ajisegiri, E.S.A. And Yisa, M.G. (2007) Fruits and vegetables handling and transportation in Nigeria. AUJT, 10(3): 175-183.

ILRI, 2011.Fruits - A synthesis of IPMS value-chain development experiences. ILRI, Nairobi.

Brecht, J. K., Yahia, E. M. \&Litz, R. E., 2009. Postharvest physiology (484-528) in Litz, R. E. (eds). The mango: botany, production and uses, 2nd edition. CABI, Oxford shire.

Kitonja, L., 2010. Identification of Appropriate Postharvest Technologies for Improving Market Access and Incomes for Small Horticultural Farmers in Sub-Saharan Africa and South Asia (318). WFLO Grant Final Report to the Bill \& Melinda Gates Foundation.

Kitinoja, L., Kader, A.A., 2002. Small-Scale Postharvest Handling Practices: A Manual for Horticultural Crops, fourth ed. University of California, Postharvest Technology Research and Information Center, Davis.

Kader, A.A. (2005) Increasing food availability by reducing postharvest losses of fresh produce. Acta Horticulture, 682: 2169-2175.

Kader, A.A. (2003) Perspective on postharvest horticulture. Horticultural Science, 38: 1004-1008. KADER, A.A. AND ROLLE, R.S. (2004) The role of post-harvest management in assuring the quality and safety of 
horticultural produce. Rome: FAO.

Kader, A. A., 2003. A perspective on postharvest horticulture (1978-2003).hortscience, 38, 5:1004-1008.

Kitonja, L., 2010. Identification of Appropriate Postharvest Technologies for Improving Market Access and Incomes for Small Horticultural Farmers in Sub-Saharan Africa and South Asia (318). WFLO Grant Final Report to the Bill \& Melinda Gates Foundation.

Kitinoja, L. (2013) Returnable Plastic Crate (RPC) systems can reduce postharvest losses and improve earnings for fresh produce operations. PEF White Paper No. 13-01. Oregon: The Postharvest Education Foundation.

Kughur PG, Iornenge GM, Ityonongu BE (2015). Effects of postharvest losses on selected fruits and vegetables among small-scale farmers in Gboko local government area of Benue State, Nigeria. Int. J. Innov. Sci. Res. 19(1):201-208.

Labadarios, D. (ed). (2000). The National Food Consumption Survey (NFCS): Children aged 1-9 years, South Africa, 1999. Pretoria: Directorate of Nutrition, Department of Health.

Mbuk, E.M., Bassey, N.E., Udoh, E.S. And Udoh, E.J. (2011) Factors influencing postharvest loss of tomato in urban market in Uyo, Nigeria. Nigerian Journal of Agriculture, Food and Environment, 7(2): 40-46

Murphy, J. T., 2007. The challenge of upgrading in African industries: Socio-spatial factors and the urban environment in Mwanza, Tanzania. World Development, 35, 10:1754-1778

Olayemi, F.F., Adegbola, J.A., Bamishaiye, E.I., Daura, A.M., 2010. Assessment of post-harvest challenges of small scale farm holders of tomatoes, bell and hot pepper in some local government areas of Kano State, Nigeria.Bayero J. Pure Appl. Sci. 3, 39-42

Parfitt, J., Barthel, M. \&Macnaughton, S., 2010. Review Food waste within food supply chains: quantification and potential for change to 2050. Philosophical Transactions of the Royal Society B: Biological Sciences, $365,1554: 3065-3081$.

Ruben, R., van Tilburg, A., Trienekens, J., van Boekel, M., 2007. Linking market integration, supply chain governance, quality, and value added in tropical food chains (13-46) in Ruben, R. (eds). Tropical food chains: governance regimes for quality management. Wageningen Academic Pub., Wageningen.

Ruel, M. T., Minot, N. \& Smith, L. 2005. Patterns and determinants of fruit and vegetable consumption in subSaharan Africa: a multi country comparison, WHO Geneva.

Rutten, M. \& Kavallari, A. 2013. Can reductions in agricultural food losses avoid some of the trade-offs involved when safeguarding domestic food security

Salin, V., 1998. Information technology in agri-food supply chains. International Food and Agribusiness Management Review, 1, 3:329-34

Singh, A., Singh, Y., 1992. Effect of vibration during transportation on the quality of tomatoes. J. Agric. Mech. Asia Afr. Latin Am. 23, 70-72.

Sirivatanapa, S., 2006.Packaging and transportation of fruits and vegetables for better marketing. In: Rolle, R.S. (Ed.), Postharvest Management of Fruit and Vegetables in the Asia-Pacific Region.

Shukla, M., \&Jharkharia, S., 2013.Agri-fresh produce supply chain management: a state-of-the-art literature review. International Journal of Operations \& Production Management, 33, 2:114-158

Wakijira, M., 2010.Solar drying of fruits and windows of opportunities in Ethiopia. African Journal of Food Science, 4, 13:790-802

Weinberger, K. \& Lumpkin, T. A., 2007. Diversification into horticulture and poverty reduction: a research agenda. World Development 2007, 35, 8:1464-1480.

Wei, S., Woods, E., Adar, D., Singgih, S., 2001.West Timor mandarin marketing case study implications for supply-chain management in developing countries. In: O’Hare, T., Bagshaw, J., Li, W., Johnson, G.I. (Eds.), Postharvest Handling of Fresh Vegetables. Proceedings of a Workshop Held in Beijing, People's Republic of China, 9-11 May 2001. ACIAR Proceedings No. 105, p. 126.

Wiersinga, R., de Jager, A., 2009. In: Business Opportunities in the Ethiopian Fruit and Vegetable Sector. Wageningen University and Research Centre - LEI, p. 46.

Wills, R.B.H., Mcglasson, W.B., Graham, D. And Joyce, D.C. (2007) Postharvest - An introduction to the physiology and handling of fruits, vegetables and ornamentals. 5 th Ed. Oxford shire: CAB International.

World Bank, W. 2014. Missing Food: The Case of Postharvest Grain Losses in Sub- Saharan Africa 